\title{
ANALISIS PENGARUH EFISIENSI MODAL KERJA TERHADAP PROFITABILITAS PADA PT. KRAKATAU STEEL, TBK
}

\author{
Afandi $^{1 \cdot}$ Iroh Rahmawati \\ Universitas Banten Jaya \\ Serang, Indonesia \\ $\underline{\text { afandi14011995@gmail.com }}{ }^{1}, \underline{\text { irohrahma@gmail.com }}{ }^{2}$
}

\begin{abstract}
This study aims to find out how the Efficiency Analysis of Working Capital Against Profitability at PT. Krakatau Steel,Tbk.This study uses a quantirative method. The population in this study is te overallfinancial statements of PT. Krakatau Steel, Tbk in the year (2014-2017), while the sample in this study is the balance sheet and income statement for the year (2014-2017). The technique of data collection is done by documentation and library techniques. The data analysis technique used is simple linear regression. The results of this study indicate that working capital has no significant effect on profitability at PT. Krakatau Steel, Tbk.
\end{abstract}

Keywords: Working Capital, Profitability

\section{PENDAHULUAN}

Modal Kerja adalah masalah pokok dan topik penting yang sering kali dihadapi oleh perusahaan, karena hampir semua perhatian terfokus dalam mengelola modal kerja dan aktiva lancar yang merupakan bagian yang cukup besar dari aktiva.

Modal kerja dibutuhkan oleh setiap perusahaan untuk membiayai operasinya sehari-hari, misalnya : untuk pengeluaran uang muka pembelian bahan mentah, membiayai upah gaji pegawai, dan lainlain, dimana uang atau dana yang dikeluarkan diharapkan dapat kembali lagi masuk ke perusahaan dalam waktu singkat melalui hasil penjualan produksinya. Oleh karena itu, perusahaan dituntut untuk untuk selalu meningkatkan efisiensi kerjanya sehingga tercapai tujuan yang diharapkan oleh perusahaan yaitu mencapai laba yang optimal.

Salah satu masalah kebijakan keuangan yang dihadapi oleh setiap perusahaan adalah masalah efisiensi modal kerja. Manajemen modal kerja sangat penting dalam keuangan karena kesalahan dan kekeliruan dalam mengelola modal kerja dapat mengakibatkan kegiatan usaha menjadi terhambat atau terhenti sama 
sekali. Sehingga, adanya analisis atas modal kerja perusahaan sangat penting dilakukan untuk mengetahui situasi modal kerja saat ini, kemudian hal itu dihubungkan dengan situasi keuangan yang akan dihadapi pada masa yang akan datang. Informasi ini dapat ditentukan program apa yang harus atau langkah apa yang harus diambil untuk mengatasinya. Pengelolaan modal kerja adalah hal yang sangat penting dalam perusahaan, karena meliputi dalam pengambilan keputusan mengenai jumlah dan komposisi aktiva lancar dan bagaimana membiayai aktiva ini.

Perusahaan yang kurang memperhitungkan tingkat modal kerja yang optimal, maka perusahaan kemungkinan mengalami insolvency (tak mampu memenuhi kewajiban jatuh tempo) dan mungkin bahkan terpaksa harus dilikuidasi. Aktiva lancar yang dimiliki oleh setiap perusahaan harus cukup besar untuk dapat menutup hutang lancar sedemikian rupa, sehingga menggambarkan adanya tingkat keamanan (margin safety) yang memuaskan.

Sementara itu, jika perusahaan menetapkan modal kerja yang berlebih akan menyebabkan perusahaa overlikuid sehingga menimbulkan inefisensi perusahaan, dan membuang kesempatan memperoleh laba. Modal kerja memiliki sifat yang sangat fleksibel besar kecilnya modal kerja dapat ditambah atau dikurangi sesuai dengan kebutuhan perusahaan.

Menetapkan modal kerja yang terdiri atas kas, piutang, persediaan yang harus dimanfaatkan seefisien mungkin. Besarnya modal kerja harus sesuai dengan kebutuhan perusahaan, karena baik kelebihan atau kekurangan modal kerja sama-sama membawa dampak negative bagi perusahaan. Modal kerja yang berlebihan terutama modal kerja dalam bentuk uang tunai dan surat berharga dapat merugikan perusahaan karena menyebabkan dana yang besar tanpa digunakan secara produktif.

Dana yang mengendap merupakan dana-dana yang tidak digunakan menyebabkan diadakannya investasi dalam proyek-proyek yang tidak diperlukan dan tidak produktif. Disamping itu kelebihan modal kerja juga dapat menimbulkan inefisiensi atau pemborosan dalam kegiatan operasi perusahaan. Indikator adanya manajemen modal kerja yang baik adalah efisiensi modal kerja. Modal kerja bisa dilihat dari perputaran modal kerja (working capital turnover), perputaran piutang (receivable turnover) dan perputaran persediaan (inventory turnover). Perputaran modal kerja dimulai dari saat kas diinvestasikan dalam 
komponen modal kerja sampai saat menjadi kas. Makin sedikit periode perputaran modal kerja, makin cepat perputarannya sehingga perputaran modal kerja makin tinggi dan perusahaan makin efisien yang pada akhirnya rentabilitas semakin meningkat (Kasmir, 2012: 176178)

Rasio-rasio yang digunakan dalam mengukur efisiensi modal kerja adalah :

\section{Perputaran Modal Kerja}

(Working Capital Turnover)

Rasio ini menunjukkan banyaknya penjualan (dalam rupiah) yang

diperoleh perusahaan untuk tiap rupiah modal kerja. Menurut (Kasmir, 2012: 182-183) Formulasi dari Working Capital Turnover adalah sebagai berikut :

WCT $=\frac{\text { Penjualan }}{\text { Modal Kerja }}$

Rata-rata industri perputaran modal kerja (working capital turnover) adalah 6 kali.

2. Perputara Persediaan

(Inventory

Turnover)

Rasio ini mengukur efisiensi pengelolaan Persediaan barang dagang. Rasio ini merupakan rasio yang sangat popular untuk menilai efisiensi operasional, yang memperlihatkan seberapa

baiknya manajemen mengontrol modal pada persediaan. Menuru (Kasmir, 2012: 180-181) Formulasi dari Inventory Turnover adalah sebagai berikut :

Inventory Turnover $=\frac{\text { Penjualan }}{\text { Sediaan }}$

Rata-rata industri perputaran persediaan (inventory turnover) adalah 20 kali.

3. Perputaran Piutang (Receivable Turnover)

Rasio ini menunjukkan efisiensi pengelolaan piutang perusahaan. Semakin tinggi rasio menunjukkan modal kerja yang ditanamkan dalam piutang rendah. Menurut (Kasmir, 2012: 176- 177) Formulasi dari Receivable Turn Over adalah sebagai berikut :

$$
\mathrm{RT}=\frac{\text { Penjualan } \text { kredit }}{\text { Piutang }}
$$

Rata-rata industri perputaran modal kerja (receivable turnover) adalah 15 kali.

Beberapa rasio yang digunakan dalam mengukur profitabilitas adalah sebagai berikut :

a. Profit Margin on Sales

Terdapat dua rumus untuk mencari profit margin, yaitu sebagai berikut:

1) Untuk margin laba kotor Margin laba kotor menunjukkan laba yang relative terhadap perusahaan, dengan cara penjualan 
bersih dikurangi harga pokok penjualan. Rasio ini merupakan cara dalam menetapkan harga pokok penjualan. Menurut (Kasmir, 2012: 199-200) Formulasi dari profit margin atau PM adalah sebagai berikut :

$\mathrm{PM}=\frac{\text { Penjualan bersih }- \text { hpp }}{\text { Sales }} \times 100 \%$

Rata-rata industri profit margin on sales untuk margin laba kotor adalah $30 \%$.

1) Untuk margin laba bersih

Net Profit Margin (NPM)

Merupakan ukuran keuntungan yang membandingkan antara laba setelah bunga dan pajak dibandingkan dengan penjualan. Rasio ini yang menunjukkan pendapatan bersih perusahaan atas penjualan.

Menurut (Kamir, 2012: 200

-201) Formulasi dari Net profit margin atau NPM adalah sebagai berikut:

$\mathrm{NPM}=\frac{E A T}{\text { Sales }} \times 100 \%$

Rata-rata industri untuk margin laba bersih (net profit margin) adalah $20 \%$

\section{b. Return on Investment}

Return on Investment (ROI) adalah rasio yang menunjukkan hasil (return) atas jumlah aktiva yang digunakan dalam perusahaan. ROI juga merupakan suatu ukuran efektivitas manajemen dalam mengelola investasinya. Menurut (Kasmir, 2012: 201-202) Formulasi dari return on investment atau ROI adalah sebagai berikut:

$\mathrm{ROI}=\frac{\text { Earning After Interest and Tax }}{\text { Total Aseet }} \times 100 \%$ Rata-rata industri Return on Investment (ROI) adalah $40 \%$.

c. Return on Equity

Return on equity (ROE) adalah rasio dalam mengukur laba bersih sesudah pajak dengan modal sendiri. Rasio ini menunjukkan efisiensi penggunaan modal sendiri. Semakin tinggi rasio ini, semakin baik. Artinya posisi pemilik perusahaan semakin kuat, demikian pula sebaliknya. Menurut (Kasmir, 2012:201-202)

Formulasi dari return on equity atau ROE adalah sebagai berikut:

$\mathrm{ROE}=\frac{\text { Earing After Interest and } \operatorname{Tax}}{\text { Equity }} \times 100 \%$ Rata-rata industri Return on Equity (ROE) adalah $40 \%$.

\section{METODE PENELITIAN}

Jenis penelitian yang digunakan dalam penelitian ini adalah analisis data kuantitatif yaitu: yakni menguji dan menganalisis data dengan perhitungan angka-angka dan kemudian menarik kesimpulan dari pengujian tersebut. 
Populasi dalam penelitian ini adalah laporan keuangan yang diterbitkan langsung oleh PT. Krakatau Steel, Tbk yang mana perusahaan ini mengalami kerugian dalam beberapa tahun terakhir. Sedangkan sampel yang diambil dalam penelitian ini adalah laporan keuangan dari tahun 2014 - 2017.

Metode penarikan sampel yang digunakan dalam penelitian ini adalah purposive sampling, yaitu sampel yang pemilihan elemennya berdasarkan pertimbangan secara subjektif.

Untuk menjawab rumusan masalah yaitu apakah efisiensi modal kerja berpengaruh secara signifikan terhadap rasio profitabilitas, dilakukan dalam tiga langkah yaitu analisis efisiensi modal kerja (variabel $\mathrm{X}$ ), analisis Profitabilitas (variabel Y) dan analisis pengaruh signifikan efisiensi modal keja terhadap profitabilitas (NPM dan ROE).

HASIL PENELITIAN

DAN

\section{PEMBAHASAN}

1. Analisis Modal Kerja Bersih PT. Krakatau Steel, Tbk Modal kerja adalah dana yang harus tersedia untuk membiayai kegiatan operasional perusahaan PT. Krakatau Steel, Tbk sehari-hari dan kewajiban lainnya seperti membeli bahan baku, membayar hutang dan sebagainya. Dimana dana yang telah dikeluarkan tersebut diharapkan akan kembali dalam jangka waktu yang relatif pendek melalui hasil penjualan produksinya yang akan digunakan untuk operasi selanjutnya. Dalam penelitian ini penulis menggunakan modal kerja bersih sebagai alat untuk mengukur kemampuan perusahaan dalam membiayai kegiatan operasionalnya.

a. Perputaran Modal Kerja (Working Capital Turn Over)

Untuk Tahun 2014 :

$\mathrm{WCT}=\frac{1.868 .845}{972.831}=1,92 \mathrm{kali}$

Perputaran modal kerja pada tahun 2014 sebanyak 1,9 kali. Artinya setiap $\$ 1,00$ modal kerja dapat menghasilkan $\$ 1,9$ penjualan.

Untuk Tahun 2015 :

$\mathrm{WCT}=\frac{1.321 .823}{972.831}=1,36 \mathrm{kali}$

Perputaran modal kerja pada tahun 2015 sebanyak 1,4 kali. Artinya setiap $\$ 1,00$ modal kerja dapat menghasilkan $\$ 1,4$ penjualan.

Untuk Tahun 2016 :

$\mathrm{WCT}=\frac{1.344 .715}{1 \cdot 109.710}=1,21 \mathrm{kali}$

Perputaran modal kerja pada tahun 2016 sebanyak 1,2 kali. Artinya setiap $\$ 1,00$ modal kerja dapat menghasilkan $\$ 1,2$ penjualan. 
Untuk Tahun 2017 :

$\mathrm{WCT}=\frac{1 \cdot 449.020}{1 \cdot 109 \cdot 710}=1,30 \mathrm{kali}$

Perputaran modal kerja pada tahun 2017

sebanyak 1,3 kali. Artinya setiap $\$ 1,00$ modal kerja dapat menghasilkan $\$ 1,3$ penjualan.

b. Perputaran Persedian (Inventory Turn Over)

Untuk Tahun 2014 :

IT $=\frac{1.868 .845}{480.871}=3,8 \mathrm{kali}$

Persediaan pada tahun 2014 sebanyak 4 kali. Artinya rasio ini menunjukkan 4 kali persediaan barang dagangan diganti dalam satu tahun.

Untuk Tahun 2015 :

$$
\mathrm{IT}=\frac{1.321 .823}{408.870}=3,2 \mathrm{kali}
$$

Persediaan pada tahun 2015 sebanyak 3 kali. Artinya rasio ini menunjukkan 3 kali persediaan barang dagangan diganti dalam satu tahun.

Untuk Tahun 2016 :

IT $=\frac{1.344 .715}{473.956}=2,8 \mathrm{kali}$

Persediaan pada tahun 2016 sebanyak 3 kali. Artinya rasio ini menunjukkan 3 kali persediaan barang dagangan diganti dalam satu tahun.
Untuk Tahun 2017 :

IT $=\frac{1.449 .020}{488.502}=2,9 \mathrm{kali} / 3 \mathrm{kali}$

Persediaan pada tahun 2017 sebanyak 3 kali. Artinya rasio ini menunjukkan 3 kali persediaan barang dagangan diganti dalam satu tahun.

Berdasarkan hasil diatas dapat diketahui dari hasil Working Capital Turnover dan hasil Inventory Turnover PT. Krakatau Steel, Tbk pada tahun 2014-2017 berada dibawah rata-rata industri. Hal ini menunjukkan keadaann perusahaan pada periode tersebut dinilai kurang baik karena masih dibawah rata-rata industri. Artinya jika dilihat dari rata-rata industri rasio Working Capital Turnover setiap \$1 modal kerja dapat menghasilkan \$6 penjualan. Sementara rasio yang dimiliki perusahaan hanya $\$ 1,9$ pada tahun $2014, \$ 1,4$ pada tahun 2015, \$1,2 pada tahun 2016 dan $\$ 1,3$ pada tahun 2017. Dan jika dilihat dari ratarata industri rasio Inventory Turnover menunjukkan 20 kali persediaan diganti dalam satu tahun.

Sementara rasio yang dimiliki perusahaan hanya 4 kali pada tahun 2014 dan 3 kali pada tahun 2015-2017. Dalam hal ini manajemen harus bekerja lebih keras lagi untuk meningkatkan rasio Working Capital Turnover dan Inventory Turnover seperti mengatur modal kerja dan persediaan agar 
dapat digunakan seefisien mungkin sesuai yang dibutuhkan oleh perusahaan sehingga minimal mencapai atau sama dengan rasio rata-rata industri.

2. Analisis Rasio Profitabilitas

Profitabilitas merupakan kemampuan yang dimiliki perusahaan dalam menghasilkan laba. Oleh karena itu profitabilitas dapat diketahui dari laba bersih yang diperoleh perusahaan pada setiap penjualan bersih yang dilakukan.

a. Net Profit Margin (NPM)

Untuk Tahun 2014 :

$\mathrm{NPM}=\frac{-154.185}{1.868 .845} \times 100 \%$

$\mathrm{NPM}=-0,0825$

Untuk Tahun 2015 :

$\mathrm{NPM}=\frac{-326.514}{1.321 .823} \times 100 \%$

$\mathrm{NPM}=-0,2470$

Untuk Tahun 2016 :

$\mathrm{NPM}=\frac{-180.724}{1.345 .715} \times 100 \%$

$\mathrm{NPM}=-0,1342$

Untuk Tahun 2017 :

$\mathrm{NPM}=\frac{-86.097}{1.449 .020} \times 100 \%$

$\mathrm{NPM}=-0,0594$

\section{b. Return On Equity}

Untuk Tahun 2014 :
$\mathrm{ROE}=\frac{-154.185}{885.933} \times 100 \%$

$\mathrm{ROE}=-0,1740$

Untuk Tahun 2015 :

$\mathrm{ROE}=\frac{-326.514}{1.788 .104} \times 100 \%$

$\mathrm{ROE}=-0,1826$

Untuk Tahun 2016 :

$\mathrm{ROE}=\frac{-180.724}{1.839 .677} \times 100 \%$

$\mathrm{ROE}=-0,0982$

Untuk Tahun 2017 :

$\mathrm{ROE}=\frac{-86.097}{1.852 .805} \times 100 \%$

$\mathrm{ROE}=-0,0464$

Berdasarkan analisis diatas dapat diketahui dari hasil Net Profit Margin dan hasil Return On Equity PT. Krakatau Steel, Tbk pada tahun 2014-2017 berada dibawah rata-rata industri. Hal ini menunjukkan keadaann perusahaan pada periode tersebut dinilai kurang baik karena masih dibawah rata-rata industri. Artinya jika dilihat dari rata-rata industri rasio

Net Profit Margin menunjukkan sebesar $20 \%$. Sementara rasio yang dimiliki perusahaan hanya $-8,2 \%$ pada tahun 2014 , $24,7 \%$ pada tahun $2015,-13,4 \%$ pada tahun 2016 dan $-5,9 \%$ pada tahun 2017. Dan jika dilihat dari rata-rata industri rasio Return On Equity menunjukkan sebesar $40 \%$. Sementara rasio yang dimiliki perusahaan hanya $-17,4 \%$ pada tahun $2014,-18,3 \%$ pada tahun $2015,-9,8 \%$ pada tahun 2016 
dan $-4,6 \%$ pada tahun 2017. Dalam hal ini manajemen harus bekerja lebih keras lagi untuk meningkatkan rasio Net Profit Margin dan Return On Equity hingga minimal mencapai atau sama dengan rasio rata-rata industri.

\section{Uji Normalitas}

Dasar pengambilan keputusan :

- Jika nilai signifikansi > 0.05 , maka nilai residual berdistribusi normal.

- Jika nilai signifikansi $<0.05$, maka nilai residual tidak berdistribusi normal.

Berdasarkan hasil uji normalitas diketahui nilai signifikansi 0,981 >0.05, maka dapat disimpulkan bahwa nilai residual berdistribusi normal.

2. Analisis Regresi Linier Sederhana

\section{a. Hasil Analisis Regresi}

Linear Sederhana

Modal Kerja (X) Terhadap

Pofitabilitas (Y) Persamaan regresi linear sederhana, maka hasilnya sebagai berikut:

$\mathrm{Y}=-21,950+6,138 \mathrm{Y}$

Maka dari persamaan diatas yaitu:

- Konstanta sebesar -21,950, mengandung arti bahwa nilai konsisten variabel profitabilitas pada PT. Krakatau Steel, Tbk adalah sebesar -21,950.
- Koefisien regresi (X) sebesar 6,138 menyatakan bahwa setiap penambahan $1 \%$ nilai modal kerja, maka nilai profitabilitas pada PT. Krakatau Steel, Tbk sebesar 6,138. Koefisien regresi tersebut bernilai positif, sehingga dapat dikatakan bahwa arah pengaruh variabel $\mathrm{X}$ terhadap Y adalah positif.

\section{Uji Koefisien Determinasi}

Koefisien determinasi ini digunakan untuk mengetahui seberapa besar pengaruh variabel-variabel bebas memiliki pengaruh terhadap variabel berikutnya. Dari hasil perhitungan SPSS 20.0 pada tabel 4.7 dapat diketahui bahwa koefisien determinasi ( $\mathrm{R}$ square) yang diperoleh sebesar 0,052 atau $5,2 \%$. Artinya variabel bebas $(\mathrm{X})$ yaitu modal kerja mampu memberikan kontribusi pengaruh sebesar 5,2\% terhadap variabel terikat (Y) yaitu profitabilitas. Sisanya sebesar $94,8 \%$ dipengaruhi oleh faktorfaktor lain yang tidak diteliti dalam penelitian ini.

\section{Uji t Parsial}

Dari perhitungan diperoleh nilai sebesar 4,303. Hasil tersebut menunjukkan bahwa < karena nilai 0,331 lebih kecil dar 4,303 artinya modal kerja tidak berpengaruh signifikan terhadap profitabilitas. 
Penelitian ini bertujuan untuk mengetahui bagaimana pengaruh modal kerja terhadap profitabilitas pada PT. Krakatau Steel, Tbk dikota Cilegon. Secara teori nilai rata-rata industri untuk modal kerja yang diukur dengan Working Capital Turnover adalah 6 kali dan Inventory Turnover adalah 20 kali. Sedangkan untuk profitabilitas yang diukur dengan Net Profit Margin sebesar 20\% dan Return On Equity Sebesar 40\%. Namun kondisi perputaran modal kerja dan profitabilitas yang terjadi pada PT. Krakatau Steel, Tbk yang di teliti oleh penulis menunjukan nilai setiap tahunnya dibawah nilai rata-rata industri.

Untuk mengetahui pengaruh modal kerja terhadap profitabilitas pada PT. Krakatau Steel, Tbk di kota Cilegon. Didapat hasil perhitungan analisis regresi linear sederhana diatas antara modal kerja (X) terhadap profitabilitas $\quad(Y)$. Maka diperoleh koefisien regresi sebesar -21,950 yang artinya, jika modal kerja mengalami kenaikan sebesar 1 kali, maka profitabilitas (Y) juga mengalami peningkatan sebesar 6,138 kali. Dan dari uji koefisien determinasi didapatkan hasil 5,2\%. Artinya variabel bebas modal kerja (X) mampu memberikan pengaruh sebesar 5,2\% terhadap variabel terikat (Y) dan sisanya sebesar 94,8\% dipengaruhi oleh faktor lain yang tidak diteliti.
Berdasarkan perhitungan diperoleh nilai $t_{\text {tabel }}$ sebesar 4,303. Hasil tersebut menunjukkan bahwa $t_{\text {hitung }}<t_{\text {tabel }}$ karena nilai thitung $\quad 0,331$ lebih kecil dari $\mathrm{t}_{\text {tabel }} \quad 4,303$ artinya modal kerja tidak berpengaruh signifikan terhadap profitabilitas, Penelitian ini sesuai dengan penelitian yang dilakukan oleh Faurani(2004), yang menyatakan bahwa modal kerja tidak begitu berpengaruh terhadap profitabilitas akan tetapi bisa dipengaruhi oleh faktor lain.

\section{DAFTAR PUSTAKA}

Agustinus, Michael. 2016. "Rugi Rp 1,2 T di Semester I, Ini Penjelasan Krakatau Steel”. Online. Tersedia.

https://finance.detik.com/bursa-dan-valas/d3279961/rugi-rp-12-t-di-semester-iini-penjelasan-krakatau-steel. (14 Maret 2019).

https://id.wikipedia.org/wiki/Krakatau_Steel (perusahaan) ( 14 Mei 2019 Pukul. 20.00)

http $/ /$ www.krakatausteel.com/laporan_keua ngan perusahaan ( 15 April 2019 Pukul. 21.00 )

Astuti, Indri. 2003." Pengaruh Manajemen Modal Kerja Terhadap Profitabilitas Perusahaan Automotive and Allied Product Yang Go Publik di BEJ”. 
Brigham, F, Eugene, dan Houston, F, Joel. 2011. Manajemen Keuangan. Jakarta: Erlangga.

Dani. 2003. "Pengaruh Likuiditas, Leverage dan Efisiensi Modal Kerja Terhadap

Profitabilitas (Studi Kasus Pada PT Modern Toolsindo Bekasi)".

Faurani Santi Singangerda 2004. "Analisis Pengaruh Modal Kerja Terhadap Profitabilitas dan Rentabilitas Pada Koperasi Dharma Wanita Mandalika Mataram Nusa Tengggra Barat. Jurnal manajemen keuengan, volume 2, no.1. 2004

Ghozali, Imam. 2016. Aplikasi Analisis Multivariante dengan Program SPSS Edisi 2. Semarang: UNDIP.

Hanafi, M, Mamduh, Dr, MBA dan Halim, Abdul, Prof, Dr, MBA., Akt 2016. Analisis Laporan Keuangan. Yogyakarta: AMP-YKPN.

Husnan, Suad. 2008. Manajemen Keuangan teori dan Penerapan (Keputusan Jangka Panjang). Yogyakarta : BPFE

Kasmir, Dr. 2012. "Analisis Laporan Keuangan”. Jakarta: PT Raja Grafindo Persada.

Nurgraeni, Siwi. 2005. "Analisis Pengaruh Efisiensi Modal Kerja, Likuiditas, dan Solvabilitas Terhadap Profitabilitas Pada Perusahaan Property And Real Estate Yang Go Publik di Bursa Efek Jakarta".

Rangkuti, Freddy. 2015. Analisis SWOT Teknik Membedah Kasus Bisnis.
Jakarta:PT Gramedia Pustaka

Utama.

Riyanto, Bambang, Prof, Dr. 2012. Dasardasar Pembelanjaan Perusahaan. Yogyakarta: BPFE.

Santoso, Singgih. 2014. Buku Latihan SPSS Statistik Parametrik. Jakarta: PT Elex Media Komputindo.

Sawir, Agnes. 2011. Analisis Kinerja Keuangan dan Perencanaan Keuangan Perusahaan. Jakarta: PT Gramedia Pustaka Utama.

Sartono, Agus, R. Drs, MBA. 2008. Manajemen Keuangan Teori dan Aplikasi. Yogyakarta: BPFE. 